\title{
Late Triassic tectonic evolution in northwest Jutland, Denmark
}

\author{
IVAN MADIRAZZA, BO HOLM JACOBSEN and NIELS ABRAHAMSEN
}

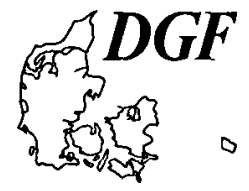

Madirazza, I., Jacobsen, B.H. and Abrahamsen, N.: Late Triassic tectonic evolution in northwest Jutland, Denmark. Bull. geol. Soc. Denmark, vol. 38, pp. 77-84. Copenhagen, April 25th, 1990. https://doi.org/10.37570/bgsd-1990-38-08

A model for the Late Triassic tectonic development in northwest Jutland is discussed in light of gravity, aeromagnetic and reflection seismic data. A wrench pull apart concept yields a simple explanation for both the present Zechstein basement configuration and the spatial distribution of salt structures in this part of the Danish basin.

Ivan Madirazza, Bo Holm Jacobsen and Niels Abrahamsen, Department of Earth Sciences, Geophysical Laboratory, University of Arhus, Finlandsgade 6-8, DK-8200 Aarhus N, Denmark, August 30th, 1989.

Presented at Basin Workshop II, Department of Earth Sciences, University of Aarhus, held April 20-22, 1989.

\section{Introduction}

The purpose of the present study is to give a plausible explanation, based on a tectonic framework, of both the present Zechstein basement configuration and the spatial distribution of salt structures in the on-shore part of the Danish Zechstein basin.

Seismic and gravity data show that a large majority of salt structures are grouped in a relatively small part of the basin in northwest Jutland, i.e. between the Fjerritslev fault in the north and the part of the basin corresponding to the Silkeborg gravity high in the south. Several, more or less generalized, maps of the Danish basin showing the locations of different salt structures were published earlier (Sorgenfrei \& Buch 1964, Sorgenfrei 1966, Madirazza 1968, 1977, 1983, 1986, Baartman 1976, Bertelsen 1980, Michelsen 1981, K. Sørensen 1986a).

Other, more fragmentary but detailed, reflection seismic studies from north Jutland are found in unpublished thesis at the Dept. of Earth Sciences, Århus, e.g.: Møller (1982) studied the development of the Skive salt structure on the basis of the gravity and seismic data; gravity modelling, based on seismic interpretation, of the Tostrup and Mors salt diapirs was presented by Petersen (1983); E. Sørensen (1986) constructed the seismic time as well as depth maps from the area of the Hyllebjerg graben (see later).
The development of the individual salt structures in northwest Jutland was treated by Baartman (1973), Madirazza (1975, 1977, 1979, 1981), Larsen \& Baumann (1982), Boldreel (1985).

The history of the North Sea Basin as a whole was formulated by Ziegler $(1981,1982)$. On the tectonic evolution of the Fennoscandian Border Zone in the Danish region see Baartman \& Christensen (1975), Liboriussen et al. (1987), and Pegrum (1984). An important contribution to the understanding of the formation of the Danish basin is the work by K. Sørensen (1986b) where he discusses the post-Early Permian evolution of this basin in terms of repeated rifting and thermal subsidence.

\section{Geophysical information}

In the present context gravimetric, magnetic and seismic data are considered. The location of three data maps with the relevant geophysical types of information (figs 2, 3 and 4) is shown in fig. 1.

\section{Gravity}

Bouguer gravity map shows that apart from the pronounced Silkeborg gravity high $(\mathrm{SH})$ a weaker gravity high (MTH) exists in the MorsThisted area (see fig. 2). The part of the basin corresponding to this area is bounded by the 


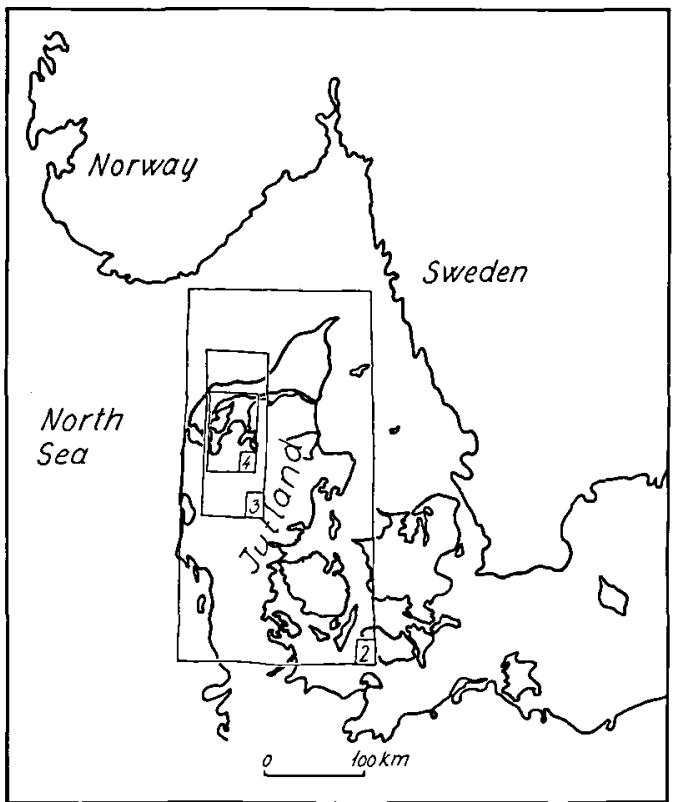

Fig. 1. The outline of Denmark and southern Scandinavian peninsula showing the location of subsequent maps (figs 2,3 , and 4).

Fjerritslev fault (F) along its north side, by the Hyllebjerg graben (HG) in the east, and it is separated from the part of the basin corresponding to the Silkeborg gravity high by the Rødding graben (RG).

These grabens are expressed as areas of low Bouguer gravity anomalies. Thus the gravity anomalies outline the main structural features in this part of the basin. A large majority of salt structures are grouped in this same part of the basin, as can be seen from the residual gravity (e.g. Petersen 1983).

On the possible causes of the Silkeborg gravity high, as well as of the magnetic anomalies in the same area, see Abrahamsen \& Madirazza (1986) and Thybo \& Schønharting (1988).

\section{Magnetics}

The aeromagnetic field, as measured at an altitude of 800 meters, is shown in fig. 3. Direct rock magnetic information from the area is not available, but expected magnetic properties of igneous and metamorphic rocks from the nearby areas of Precambrian, Lower Paleozoic, Permian, and Tertiary age may be found in the literature (e.g. Thorning \& Abrahamsen 1980, Henkel 1980, Abrahamsen \& Madirazza 1986).

The depth to the magnetic sources can be estimated using either spectral methods (e.g. Spector \& Grant 1970, Jacobsen \& Pedersen 1980) or the simpler "straight slope" measures (e.g. Vacquier et al. 1963, Hospers \& Rathore 1984). However, we have found that straight slope estimates involve a subjective calibration factor, which can vary between 0.8 and 1.3 . Thus, to this accuracy, the straight slope measurements in fig. 3 reflect the variation in depth to the magnetic sources in the area studied here. In the south the sources are shallowing due to the rise of the Ringk $\varnothing$ bingFyn High. In the remaining part of the area the sources lie uniformly deeper. Therefore the greater amplitude in the Mors-Thisted area is hardly due to the basement topography, but more likely to a difference in rock type.

Apparently, a remarkably shallow source is located parallel to the Fjerritslev fault, and close to the junction with the western boundary fault of the Hyllebjerg graben (compare with fig. 2). This could indicate the presence of a volcanic body of post-Permian age.

\section{Reflection seismics}

The north-south trending Hyllebjerg graben, which terminates against the Fjerritslev fault in the north, was studied by E. Sørensen (1986) on the basis of released seismic and well log data. The complexly faulted base Zechstein within the graben limits achieves depths of up to $9 \mathrm{~km}$. In the deeper parts the Zechstein salt is very thin, or even absent, but it thickens towards the boundary faults above which several salt structures, parallelling the faulting trend, are located. The formation of this graben can be dated to, predominantly, Keuper. The entire Triassic sequence is up to $6 \mathrm{~km}$ thick. This supports the information given by Ziegler (1981) that in restricted areas of the Danish basin the Triassic attains thicknesses of $6 \mathrm{~km}$.

In the present study we have mapped the deeper parts of the relevant reflection seismic sections (a total of $820 \mathrm{~km}$ ) covering the area of the Rødding graben and the Mors-Thisted gravity high to the western boundary fault of the Hyllebjerg graben (fig. 4). This map is based on a computer interpolation of the seismic two-way 
Fig. 2. Bouguer gravity anomalies in the Jutland peninsula (after Petersen 1983). Major structural features shown are Silkeborg gravity high (SH), MorsThisted gravity high (MTH), Rødding graben (RG), Hyllebjerg graben (HG), and Fjerritslev fault (F). For location see fig. 1 .

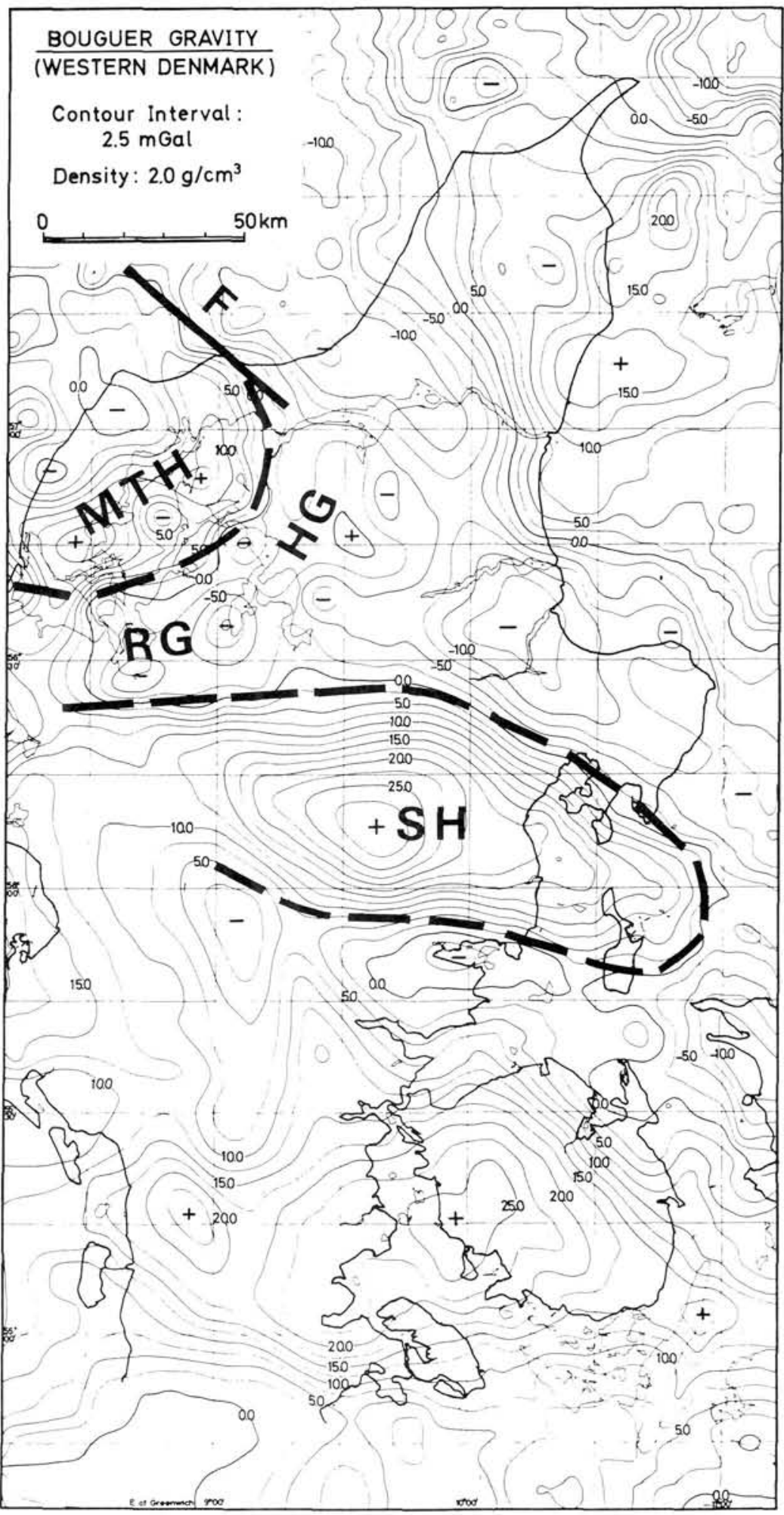




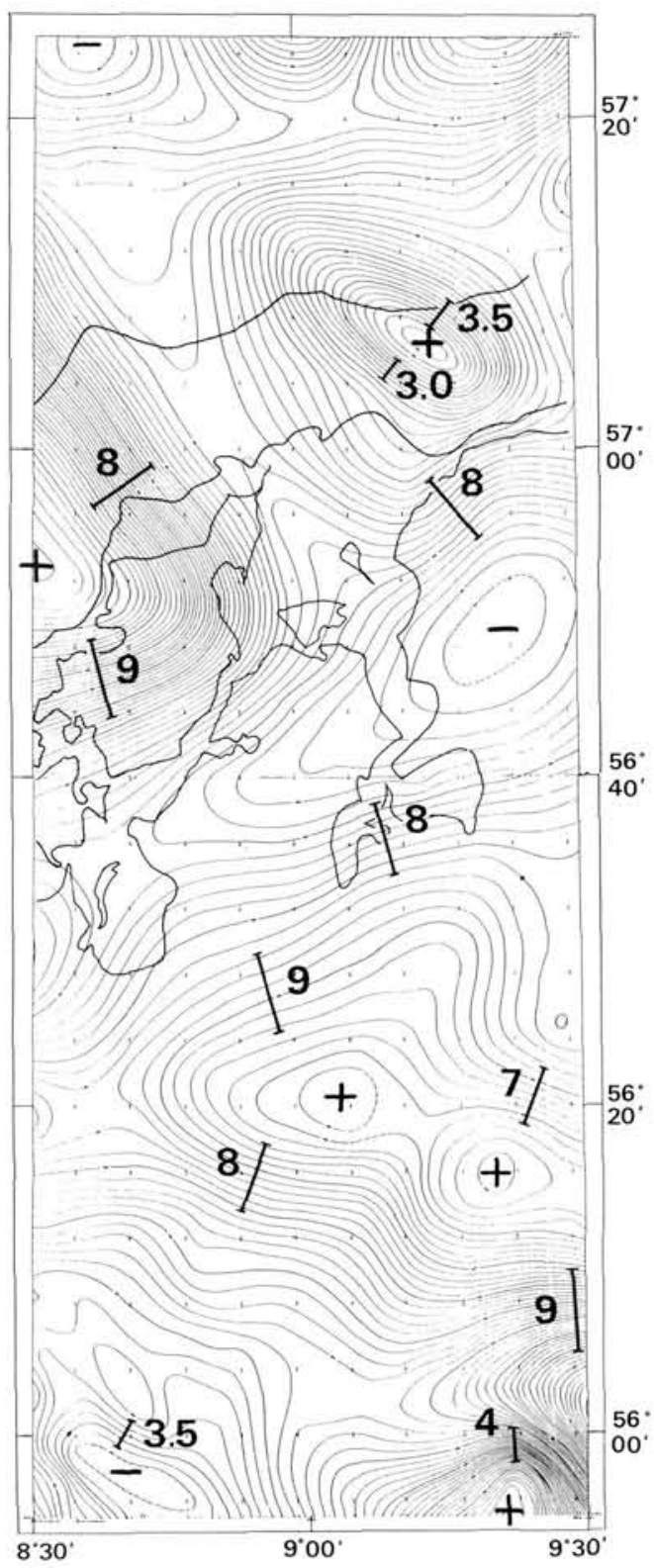

Fig. 3. Contour map of aeromagnetic data (courtesy of Marsk Oil \& Gas A/S and Danish Geological Survey). Contour interval is $10 \mathrm{nT}$. Straight slope values, given in $\mathrm{km}$, yield estimates of magnetic source depths below flight level (see text). For location see fig. 1 .

time (TWT) to the base Zechstein horizon. Ten salt structures occur within the mapped area.

The southernmost part of this area belongs structurally to the segment of the basin over- lapping the prominent Silkeborg gravity high (compare with fig. 2), where the Base Zechstein lies relatively high, at $2.7-2.8 \mathrm{sec}$ TWT. In the Mors-Thisted part of the area, which corresponds to a weaker gravity high, the base Zechstein lies slightly lower, at 3.0-3.1 sec TWT. The Zechstein salt is either absent or very thin (100-150 millisec TWT) increasing in thickness only in the vicinity of salt structures. Between the MorsThisted and Silkeborg gravity highs the base Zechstein is strongly and complexly downfaulted achieving maximal depths of up to $3.8 \mathrm{sec}$ TWT corresponding to a depth of approximately 8.5 $\mathrm{km}$.

The greatest depths ( $>3.5 \mathrm{sec}$ TWT) are found in the western part of the Rødding graben south of the island of Mors. Within this graben the Zechstein salt is either absent or very thin (100150 millisec TWT). Only in the vicinity of salt structures does the salt begin to thicken. Judging from the extraordinarily thick Keuper sediments (see e.g. Bertelsen 1980, Danm. geol. Unders. 1982), the downfaulting of this graben has taken place predominantly during the deposition of sediments of this age. Thus great similarities exist between the Rødding and Hyllebjerg grabens, both as far as their age and their structural configuration are concerned.

\section{Discussion and conclusions}

The segment of the Zechstein basin corresponding to the Silkeborg gravity high can, in a relative sense, be regarded as the stable part of the basin since, there, no major faulting has taken place and the Zechstein is essentially undisturbed having a thickness of about $1 \mathrm{~km}$ (Madirazza 1983, 1986). The overlying Triassic sequence has a rather constant thickness of about $2 \mathrm{~km}$. Assuming that in the area of the above discussed grabens the original Zechstein thickness was the same as in the Silkeborg gravity high segment of the basin, then the maximum $6 \mathrm{~km}$ thick Triassic requires downfaulting of the base Zechstein of about $3 \mathrm{~km}$ where the salt has completely withdrawn.

The maximum displacement across the Fjerritslev fault in north Jutland is also about $3 \mathrm{~km}$, and the Triassic faulting there is, predominantly, of Keuper age (e.g. Sorgenfrei 1969, Bertelsen 
Fig. 4. Interpolated two-way travel time (TWT) map of the Base Zechstein reflector covering the area of the Mors-Thisted gravity high. Rødding graben and, in the south, a northerly part of the Silkeborg gravity high (compare with fig. 2). The outlines of salt structures from the residual gravity map by Petersen (1983). For location see fig. 1.

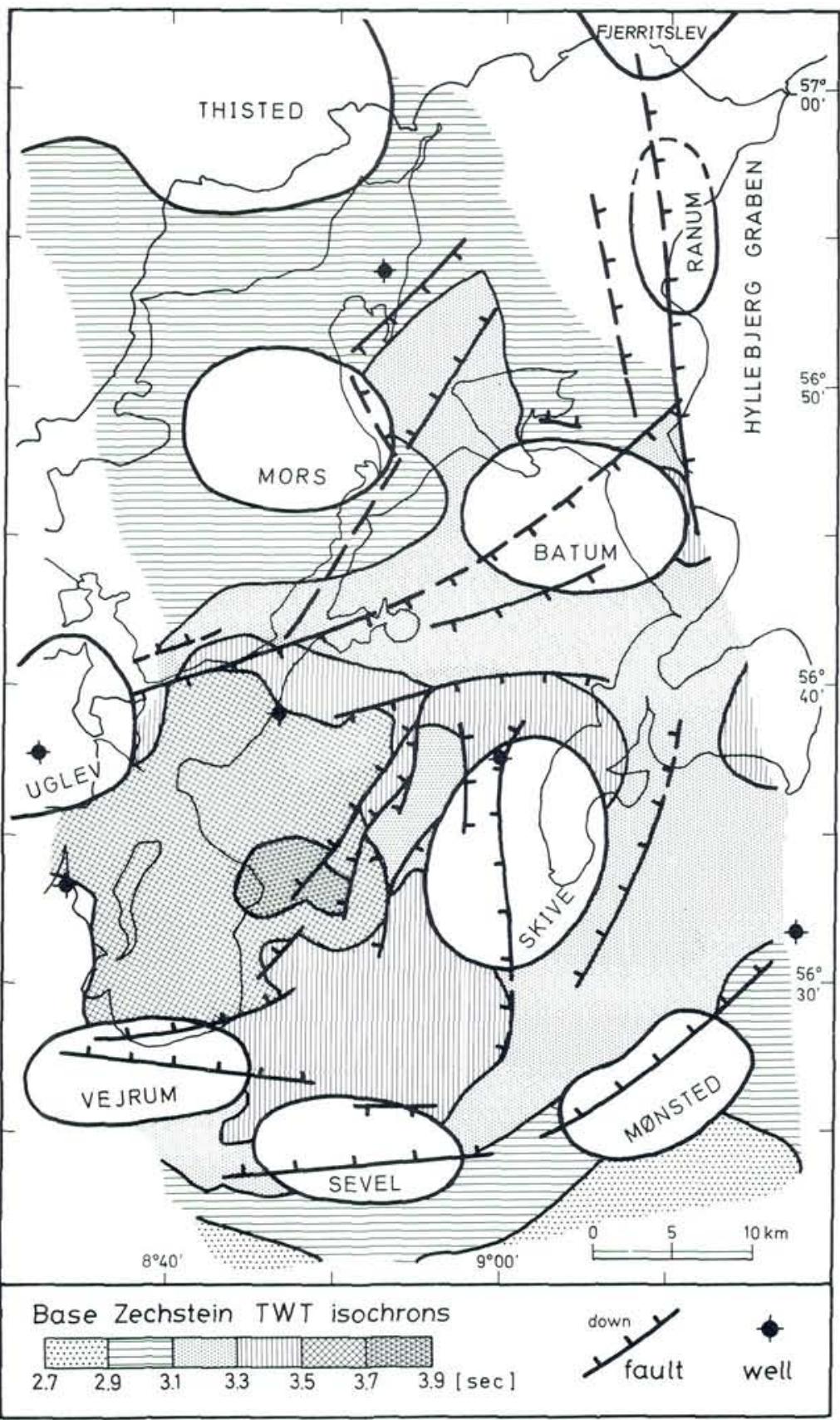

1980). According to Ziegler (1981), in northwest Europe the most likely cause of the Triassic rifting, and subsidence of the Triassic basins, was the regional crustal extension taking place along the plate boundaries.

The formation of a deep tensional structure as the Hyllebjerg graben, formed at the termination of a prominent fault - Fjerritslev fault - can be explained by the movement taking place along two en échelon dextral right-stepping strike-slip faults. As a result of such a movement tension develops. One master fault - Fjerritslev fault - is parallel to the northern side of the Mors-Thisted gravity high. The most likely other master fault is 


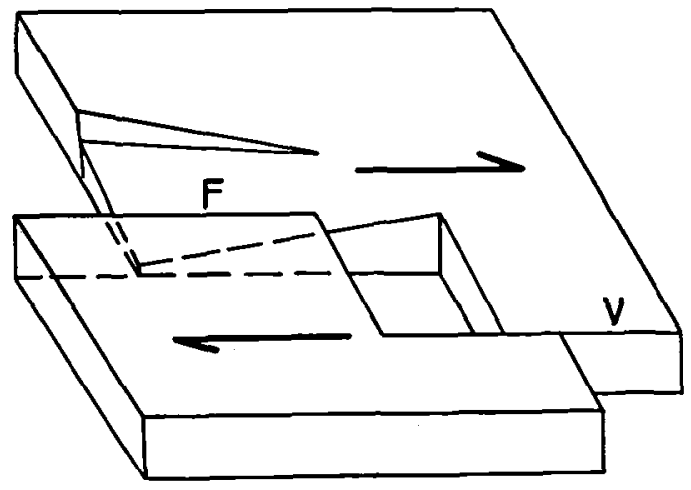

Fig. 5.A conceptual model of the formation of the pull-apart basin - Hyllebjerg graben - between the Fjerritslev (F) and Voldum (V) faults.

the fault which is parallel to the Fjerritslev fault and extends along the northeast side of the "stable" part of the basin corresponding to the Silkeborg gravity high. For the trend of this fault here referred to as the Voldum fault - see also Michelsen (1981, fig. 1) and Pegrum (1984, fig. 7).

As these two faults grow in opposite directions and gradually overlap, a pull-apart basin - Hyllebjerg graben - between them develops. This is schematically shown in fig. 5 . Penecontempora- neously with the downfaulting of the Zechstein basin floor, of maximum about $3 \mathrm{~km}$, and the deposition of extraordinarily thick Keuper sediments, the Zechstein salt withdraws from the deeper, downfaulted parts - which amplifies the apparent subsidence - and accumulates in the salt structures now typically located above the bordering faults. An analogous situation we find also in the adjoining Rødding graben (see the map, fig. 6).

The geophysical data at our disposal do not allow us to establish the exact structural relationship between the Hyllebjerg and the Rødding grabens. However, due to the above discussed great similarities concerning the ages and depths of these two grabens, as well as the distribution of salt structures in their respective areas, we assume that the Rødding graben was formed in response to the same overall extensional stress regime that was responsible for the formation of the pull-apart Hyllebjerg graben.

Moreover, the gravity and magnetic anomalies suggest that there are differences in the crustal structure between the Mors-Thisted gravity high block and the Silkeborg gravity high block, to which the "stable" part of the basin corresponds. It is thus likely that between these two blocks a pre-existing zone of weakness has facilitated the

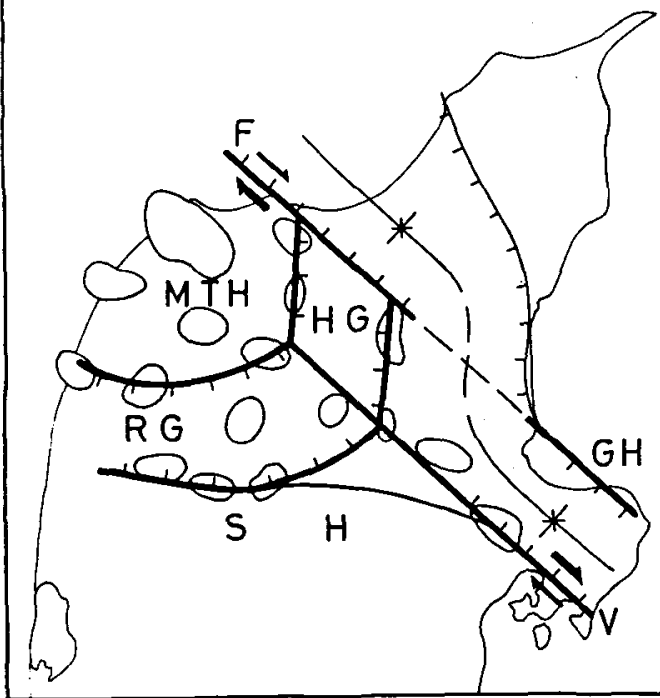

$\mathrm{SH}=$ Silkeborg gravity high

MTH = Mors - Thisted gravity high

$F=$ Fjerritslev fault

$G H=$ Grenå - Helsinger fault

$R G=$ Rodding graben

$H G=$ Hyllebjerg graben

$\mathrm{V}=$ Voldum fault

$D=$ Salt structures

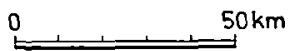

Fig. 6. A map showing the Hyllebjerg and Rødding grabens in northwest Jutland. The outlines of the salt structures according to the residual gravity map by Petersen (1983). Compare with the Bouguer gravity map of fig. 2 . For discussion see text. 
separation of these blocks subjected to extensional stresses. We have not considered direct evidence concerning the deep crustal structure, but, in general, deep basins are associated with thin crust and shallow Moho (McKenzie 1978, EUGENO-S Working Group 1988, Nielsen \& Balling 1990). It would follow that the shallowest Moho in the Danish basin is found on the downthrown side of the Fjerritslev fault and within the area of the Hyllebjerg and Rødding grabens.

The present salt structures located above the boundary faults of the Hyllebjerg and Rødding grabens are all of piercement type: Vejrum, Sevel, Mønsted, Tostrup, Harboøre, Uglev, Batum, Ranum, Fjerritslev, Suldrup, and Hvornum. The Skive pillow has developed in the shallower parts of the Rødding graben. In the area of the MorsThisted gravity high three large structures have developed: Mors, which is a diapir, and the pillows Thisted and Legind. The Voldum pillow is located above the Voldum fault along the northeast side of the Silkeborg gravity high, and another pillow - Gassum - is apparently associated with this same fault, or one of the subsidiary faults.

The pull-apart basin concept (illustrated in fig. 5) which can explain the formation of the Hyllebjerg graben, with which the Rødding graben is associated, is expected to be relevant for the understanding of the tectonic development also in other parts of the Danish basin and the surrounding areas. Thus, the north-south trending grabens, cutting the Ringkøbing-Fyn High (e.g. Horn graben), which are predominantly Triassic in age, can possibly also be explained as pullapart structures related to strike-slip movements south of the Silkeborg gravity high block.

Further geophysical testing of the applicability of the pull-apart model discussed here will include also the bordering off-shore parts of the Danish basin.

\section{Dansk sammendrag}

Den tektoniske udvikling i det nordvestlige Jylland (jfr. fig. 1) belyses ved studiet af seismiske, gravimetriske og magnetiske data, ud fra hvilke der fremstår et overordnet blok-grabenbillede. Silkeborg-blokken og Mors-Thisted-blokken markerer sig som gravimetriske maxima (jfr. fig.
2) og som områder med ensartet og relativ kort seismisk to-vejs-tid (TWT) til basis-Zechstein-reflektoren (jfr. fig. 4). Det nedforkastede bassingulv, som grænser op til disse blokke, udgør Hyllebjerg-graven og Rødding-graven. Det anomale magnetiske felts kilder (jfr. fig. 3), som typisk vil være magmatiske eller metamorfe bjergarter, synes at ligge ved eller under basis Zechstein (der ses dog en indikation på en postPerm vulkanisme ved Fjerritslevforkastningen).

Zechsteinsaltet i Hyllebjerg- og Rødding-gravene er fuldstændigt mobiliseret, og findes nu hovedsageligt som diapirer (Vejrum, Sevel, Mønsted, Tostrup, Harboøre, Uglev, Batum, Ranum, Fjerritslev, Suldrup, Hvornum, Mors), der alle, bortset fra Mors diapiren, findes over gravenes afgrænsende forkastninger. På Silkeborgblokken ligger Zechsteinsaltet stort set uforstyrret, mens Mors-Thisted-blokkens Zechsteinsalt overvejende findes i Mors-diapiren og i Thistedog Legind puderne.

Den her beskrevne model til forklaring af både forkastningsmønster og Zechsteinsaltets migration bygger på (jfr. fig. 6), at dextral forskydning langs sideværtsforkastninger, som er udviklet en échelon, medfører dannelse af lokale extensionsbassiner (jfr. fig. 5). Samtidigt aflejres i disse grave Øvre Keuper sedimenter, hvis tykkelse bliver yderligere forøget da saltet mobiliseres og akkumuleres i randligt placerede saltstrukturer. Extensionsbassiner associeres normalt med tynd skorpe, hvorfor der må ventes særligt højtliggende Moho under Hyllebjerg graven og Rødding graven. Det skal endvidere bemærkes, at denne model kan have implikationer for den tektoniske udvikling syd for Silkeborg-blokken og for den nordlige fortsættelse af gravene der skærer Ringkøbing-Fyn højderyg (e.g. Horn-graven).

\section{References}

Abrahamsen, N. \& Madirazza, I. 1986: The enigma of the Silkeborg gravity and magnetic anomalies, central Jutland, Denmark. In Møller, J.T. (ed.), Twentyfive Years of Geology in Aarhus. Geoskrifter, 24, Aarhus University, 1986, 45-59.

Baartman, J. G. 1973: Interpretation of reflection seismic work in the area around Nøvling No. 1. In Rasmussen, L. Banke (ed.), Dybdeboringen N $\emptyset$ vling Nr. 1 i Midtjylland. Danm. geol. Unders., ser. 3, 40, 34-53. 
Baartman, J. G. \& Christensen, O. Bruun 1975: Contributions to the interpretation of the Fennoscandian Border Zone. Danm. geol. Unders., ser. 2, 102, 47 pp.

Baartman, J. G. 1976: Structural outline of Denmark (a map). In Rasmussen, L. Banke, Geological aspects of the Danish North Sea sector. Danm. geol. Unders., 1976, 3, 44, 85 pp.

Bertelsen, F. 1980: Lithostratigraphy and depositional history of the Danish Triassic. Danm. geol. Unders., ser. B, 4, 59 pp.

Boldreel, L. O. 1985: On the structural development of the salt dome province in NW Jutland, Denmark, based on seismic studies. First Break, 3(8), 15-21.

Danm. geol. Unders. 1982: Well Oddesund 1. In Well data summary sheets, vol. $3,30-32$.

EUGENO-S Working Group 1988: Crustal structure and tectonic evolution of the transition between the Baltic Shield and the north German Caledonides (EUGENO-S project). Tectonophysics, 150, 253-348.

Henkel, H. 1980: Petrophysical properties (density, magnetic susceptibility and natural remanent magnetization) of rocks in Sweden. Swedish Geological Survey, Geophysical Report, 6 pp.

Hospers, J. \& Rathore, J.S. 1984: Interpretation of aeromagnetic data from the Norwegian sector of the North Sea. Geoph. Prosp., 32, 929-942.

Jacobsen, B. H. \& Petersen, L. B. 1980: Interpretation of the magnetic field from a sphere in the wavenumber domain. Pure and Applied Geophysics, 118, 1155-1169.

Larsen, G. \& Baumann, J. 1982: Trak af Mors salthorstens udvikling. Dansk geol. Foren., Årsskrift for 1981, 151-155.

Liboriussen, J., Ashton, P. \& Tygesen, T. 1987: The tectonic evolution of the Fennoscandian Border Zone in Denmark. Tectonophysics, 137, 21-29.

Madirazza, I. 1968: Mønsted and Sevel salt domes and their influence on the Quaternary morphology. Geol. Rundsch., $57,1034-1066$

Madirazza, I. 1975: The geology of the Vejrum salt structure, Denmark. Bull. geol. Soc. Denmark, 24, 161-171.

Madirazza, I. 1977: Zechstein bassinet og saltstrukturer i Nordjylland med særligt henblik på Nøvling og Paarup. Dansk geol. Foren., Årsskrift for 1976, 57-68.

Madirazza, I. 1979: Saltdiapirernes betydning for den Kvartære kronologi: Batum - et eksempel. Dansk geol. Foren., Årsskrift for $1978,7-13$.

Madirazza, I. 1981: Mere om Thisted saltstrukturen. Dansk geol. Foren., Årsskrift for 1980, 83-87.

Madirazza, I. 1983: Zechstein evaporites and salt structures of Denmark (in Polish, with English summary). Przeglad Geologiczny, 10, 553-560.

Madirazza, I. 1986. Development of salt structures in the North Danish Basin. In Møller, J. T. (ed.), Twentyfive Years of Geology in Aarhus. GeoSkrifter, 24, Aarhus University, 1986, 225-233.

McKenzie, D. 1978: Some remarks on the development of sedimentary basins. Earth Planet. Sci. Lett., 40, 25-32.
Michelsen, O. 1981 (ed.): Kortlægning af potentielle geotermiske reservoirer i Danmark. Danm. geol. Unders., ser. B, 5,96 pp.

Møller, J.J. 1982: Tre-dimensional modellering af Skive-saltstrukturen ud fra gravimetriske og seismiske data. M. Sc. thesis, Laboratory of Geophysics, Dept. of Earth Sciences, Aarhus University, vol. 1, text 93 pp., Appendix 1, 2.

Nielsen, S. B. \& Balling, N. 1990: Modelling subsidence, heat flow, and hydrocarbon generation in extensional basins. First Break, 8, 23-31.

Pegrum, R.M. 1984: The extension of the Tornquist zone in the Norwegian North Sea. Norsk geol. Tidsskrift, 64, 39-68.

Petersen, S. A. 1983: Salthorstkortlagning pả grundlag af gravi. metri kombineret med seismisk interpretation. $\mathrm{Ph} . \mathrm{D}$. thesis, Laboratory of Geophysics, Dept. of Earth Sciences. Aarhus University, vol. 1, text 114, pp., vol. 2 figs.

Sorgenfrei, T. \& Buch, A. 1964: Deep tests in Denmark 19351959. Danm. geol. Unders., 3, 36, 146 pp.

Sorgenfrei, T. 1966: Strukturgeologischer Bau von Dänemark. Geologie, 15, 6, 641-660.

Sorgenfrei, T. 1969: A review of petroleum development in Scandinavia. In Hepple, P. (ed.), The exploration for petroleum in Europe and North Africa. Institute of Petroleum (London), 191-208.

Spector, A. \& Grant, F. S. 1970. Statistical models for interpreting aeromagnetic data. Geophysics, 35, 293-302.

Sørensen, E. N. 1986: Seismisk kortlagning af HimmerlandDjursland området med sarlig vagt pa dybdekonvertering. M. Sc. thesis, Laboratory of Geophysies, Dept. of Earth Sciences, Aarhus University, vol. 1, text 142 pp., Appen$\operatorname{dix}$ A.

Sørensen, K. 1986a: Rim syncline volume estimation and salt diapirism. Nature, 319, 23-27.

Sørensen, K. 1986b: Danish Basin subsidence by Triassic rifting on a lithospheric cooling background. Nature, 319, 660663.

Thorning, L. \& Abrahamsen, N. 1980: Palaeomagnetism of Permian multiple intrusion dikes in Bohuslàn, SW Sweden. J. Roy. astr. Soc., 60, 165-186.

Thybo, H. \& Schönharting, G. 1988: Integrated geological and geophysical interpretation of the Silkeborg High, Denmark, from seismic, gravity and magnetic data (Abstract). Nordic Symposium in Earth Sciences, Tanum Strand, Sweden, 1988, 1-13.

Vacquier, V., Steenland, N. C., Henderson, R. G. \& Ziètz, I. 1963: Interpretation of aeromagnetic maps. Geol. soc. Am., Memoir, 47, 151 pp.

Ziegler, P. A. 1981: Evolution of sedimentary basins in northwest Europe. In Illing, L. V. \& Hobson, G. D. (eds), Petroleum geology of the continental shelf of north-west Europe. Institute of Petroleum (London), 1981, 3-39.

Ziegler, P.A. 1982: Geological atlas of western and central Europe. Elsevier (Amsterdam), 130 pp., with enclosures. 